Article

\title{
Increased Autotaxin Levels in Severe COVID-19, Correlating with IL-6 Levels, Endothelial Dysfunction Biomarkers, and Impaired Functions of Dendritic Cells
}

\author{
Ioanna Nikitopoulou ${ }^{1,+}$, Dionysios Fanidis ${ }^{2,+} \mathbb{D}$, Konstantinos Ntatsoulis ${ }^{2,+} \mathbb{D}$, Panagiotis Moulos ${ }^{3} \mathbb{D}_{\text {, }}$ \\ George Mpekoulis ${ }^{4}$, Maria Evangelidou ${ }^{5}$, Alice G. Vassiliou ${ }^{1}\left(\mathbb{D}\right.$, Vasiliki Dimakopoulou ${ }^{6}$, Edison Jahaj ${ }^{7}$ (D), \\ Stamatios Tsipilis ${ }^{7}$ (D), Stylianos E. Orfanos ${ }^{7}$, Ioanna Dimopoulou ${ }^{7}$, Emmanouil Angelakis ${ }^{5}$, \\ Karolina Akinosoglou ${ }^{6}$, Niki Vassilaki ${ }^{4}$, Argyrios Tzouvelekis ${ }^{6}$, Anastasia Kotanidou ${ }^{1,7}$ (D) \\ and Vassilis Aidinis $2, *$ (D)
}

check for updates

Citation: Nikitopoulou, I.; Fanidis, D.; Ntatsoulis, K.; Moulos, P.; Mpekoulis, G.; Evangelidou, M.; Vassiliou, A.G.; Dimakopoulou, V.; Jahaj, E.; Tsipilis, S.; et al. Increased Autotaxin Levels in Severe COVID-19, Correlating with IL-6 Levels, Endothelial Dysfunction Biomarkers, and Impaired Functions of Dendritic Cells. Int. J. Mol. Sci. 2021, 22, 10006. https://doi.org/10.3390/ ijms221810006

Academic Editor: Anindita Das

Received: 25 August 2021

Accepted: 11 September 2021

Published: 16 September 2021

Publisher's Note: MDPI stays neutral with regard to jurisdictional claims in published maps and institutional affiliations.

Copyright: (c) 2021 by the authors. Licensee MDPI, Basel, Switzerland. This article is an open access article distributed under the terms and conditions of the Creative Commons Attribution (CC BY) license (https:// creativecommons.org/licenses/by/ $4.0 /)$
1 GP Livanos and M Simou Laboratories, 1st Department of Critical Care \& Pulmonary Services, Medical School, National \& Kapodistrian University of Athens, Evangelismos General Hospital, 10676 Athens, Greece; joannaniki@gmail.com (I.N.); alvass75@gmail.com (A.G.V.); akotanid@med.uoa.gr (A.K.)

2 Institute of Bio-Innovation, Biomedical Sciences Research Center Alexander Fleming, 16672 Athens, Greece; fanidis@fleming.gr (D.F.); ntatsoulis@fleming.gr (K.N.)

3 Institute for Fundamental Biomedical Research, Biomedical Sciences Research Center Alexander Fleming, 16672 Athens, Greece; moulos@fleming.gr

4 Molecular Virology Laboratory, Department of Diagnostics, Hellenic Pasteur Institute, 11521 Athens, Greece; g.mpekoulis@pasteur.gr (G.M.); nikiv@pasteur.gr (N.V.)

5 Department of Diagnostics, Hellenic Pasteur Institute, 11521 Athens, Greece; meuagelidou@pasteur.gr (M.E.); e.angelakis@pasteur.gr (E.A.)

6 Department of Respiratory Medicine, University Hospital of Patras, 26504 Patras, Greece; dimakopoulou.vasilina@gmail.com (V.D.); akin@upatras.gr (K.A.); atzouvelekis@upatras.gr (A.T.)

7 1st Department of Critical Care \& Pulmonary Services, Medical School, National \& Kapodistrian University of Athens, Evangelismos General Hospital, 10676 Athens, Greece; edison.jahaj@gmail.com (E.J.); stamostsipil@gmail.com (S.T.); stylianosorfanosuoa@gmail.com (S.E.O.); idimo@otenet.gr (I.D.)

* Correspondence: V.Aidinis@Fleming.gr; Tel.: +302-109-654-382

$\dagger$ Equal contribution.

Abstract: Autotaxin (ATX; ENPP2) is a secreted lysophospholipase D catalyzing the extracellular production of lysophosphatidic acid (LPA), a pleiotropic signaling phospholipid. Genetic and pharmacologic studies have previously established a pathologic role for ATX and LPA signaling in pulmonary injury, inflammation, and fibrosis. Here, increased ENPP2 mRNA levels were detected in immune cells from nasopharyngeal swab samples of COVID-19 patients, and increased ATX serum levels were found in severe COVID-19 patients. ATX serum levels correlated with the corresponding increased serum levels of IL- 6 and endothelial damage biomarkers, suggesting an interplay of the ATX/LPA axis with hyperinflammation and the associated vascular dysfunction in COVID-19. Accordingly, dexamethasone (Dex) treatment of mechanically ventilated patients reduced ATX levels, as shown in two independent cohorts, indicating that the therapeutic benefits of Dex include the suppression of ATX. Moreover, large scale analysis of multiple single cell RNA sequencing datasets revealed the expression landscape of ENPP2 in COVID-19 and further suggested a role for ATX in the homeostasis of dendritic cells, which exhibit both numerical and functional deficits in COVID-19. Therefore, ATX has likely a multifunctional role in COVID-19 pathogenesis, suggesting that its pharmacological targeting might represent an additional therapeutic option, both during and after hospitalization.

Keywords: COVID-19; ARDS; cytokine storm; vascular dysfunction; pulmonary fibrosis; autotaxin (ATX; ENPP2); lysophosphatidic acid (LPA); dendritic cells (DCs) 


\section{Introduction}

The leading symptom of COVID-19, beyond cough and fever, is hypoxemia, leading to dyspnea in severe cases, attributed to impaired lung mechanics and/or vasoconstriction [1,2]. Endothelial dysfunction is a major characteristic of COVID-19 [3], shared with hypertension, diabetes, and obesity, the most common comorbidities that are associated with poor prognosis $[1,2]$. The respiratory epithelial cell damage that follows viral infection and replication stimulate, depending on the underlying genetic and metabolic context, a hyperinflammatory state denominated "cytokine storm" [4]. The excessive production of pro-inflammatory cytokines, such as TNF and IL-6, further induces endothelial damage and lung injury, and its more severe form, Acute Respiratory Distress Syndrome (ARDS), that can result in respiratory and/or multi-organ failure and death [5].

A subset of surviving COVID-19 ARDS-like patients will develop a fibroproliferative response characterized by fibroblast accumulation and ECM deposition [6], also evident in postmortem histopathological analysis of the lungs of COVID-19 patients [7]. Moreover, many discharged COVID-19 patients present with abnormally pulmonary architecture and functions [8-12], suggesting persisting fibrotic abnormalities, pending long-term follow up studies. Single-cell RNA sequencing (scRNAseq) analysis and transcriptional profiling indicated similarities in expression profiles between idiopathic pulmonary fibrosis (IPF) and COVID-19 [13,14], while CoV-2 infection has been suggested to stimulate the expression of major pro-fibrotic factors including TGF $\beta$ [15]. Vice versa, patients with interstitial lung diseases (ILD) had an increased risk for severe COVID-19 and poor outcomes (ICU admittance, death) following CoV-2 infection [16-18].

Autotaxin (ATX; ENPP2) is a secreted lysophospholipase D that can be found in most biological fluids, including blood and bronchoalveolar lavage fluid (BALF), largely responsible for the extracellular production of lysophosphatidic acid (LPA), a growth factor-like signaling phospholipid. Increased ATX expression and LPA signaling has been reported in cancer as well as in chronic inflammatory diseases [19], including IPF [20,21]. Genetic and pharmacologic studies have further uncovered a therapeutic potential for ATX in IPF [20,22-24], leading to phase III clinical trials [25]. Given the associations of COVID-19 with pulmonary fibrosis, the pro-fibrotic properties of ATX, as well the many reported LPA effects on pulmonary cells and especially the vasculature [26], in this study we explored a possible association of ATX with COVID-19. In this context, we quantified ENPP2 mRNA levels in nasopharyngeal swabs and ATX protein levels in the sera of two cohorts of COVID-19 patients, while we performed a large-scale analysis of recently published scRNAseq COVID-19 datasets.

\section{Results}

\subsection{Increased ENPP2 mRNA Levels in Nasopharyngeal Swab Samples from COVID-19 Patients}

As viral infections have been reported to stimulate ENPP2 mRNA expression [27,28], and to examine if CoV-2 infection has similar effects, we first quantified ENPP2 mRNA levels with Q-RT-PCR in nasopharyngeal swab samples (Table 1). A significant increase was found in ENPP2 mRNA expression in mild and severe COVID-19 patients, as compared to non-infected subjects (Figure 1). Therefore, CoV-2 infection stimulates ENPP2 mRNA expression in the respiratory epithelial or immune cells that compose the nasopharyngeal swab samples. 
Table 1. Increased ENPP2 mRNA expression in nasopharyngeal swabs from COVID-19 patients compared to healthy, non-infected controls.

\begin{tabular}{cccc}
\hline & Negative Healthy & Positive Mild & \multicolumn{2}{c}{ Positive Severe/Critical } \\
\hline Number of patients (n) & 21 & 21 & 21 \\
\hline ATX $\left(2-{ }^{\Delta \Delta C t}\right.$, mean \pm SD) & $2.15 \pm 1.37$ & $5.38 \pm 2.34^{* * * *}$ & $5.76 \pm 2.18^{* * * *}$ \\
\hline Sex & & & $17(80.95 \%)$ \\
Male & $8(38.09 \%)$ & $10(47.6 \%)$ & $4(19.04 \%)$ \\
Female & $13(61.9 \%)$ & $9(42.8 \%)$ & 0 \\
Not recorded & 0 & $2(9.52 \%)$ & $63.38 \pm 17.23$ \\
\hline Age (years, mean \pm SD) & $50.15 \pm 20.86$ & $37.78 \pm 11.89$ & \\
\hline
\end{tabular}

Statistical significance was assessed with one-way ANOVA followed by Bonferroni post hoc correction; ${ }^{* * *}$ denotes $p<0.0001$. ATX values are presented at Figure 1.

A

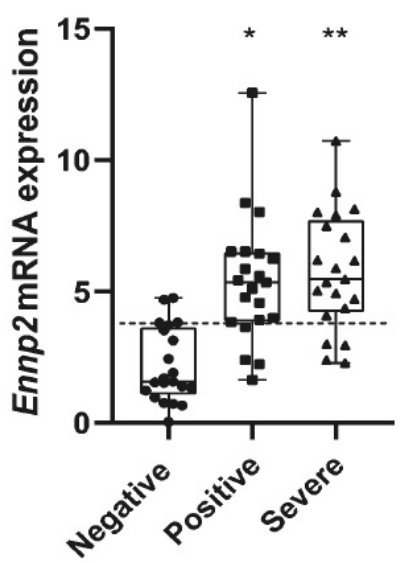

B

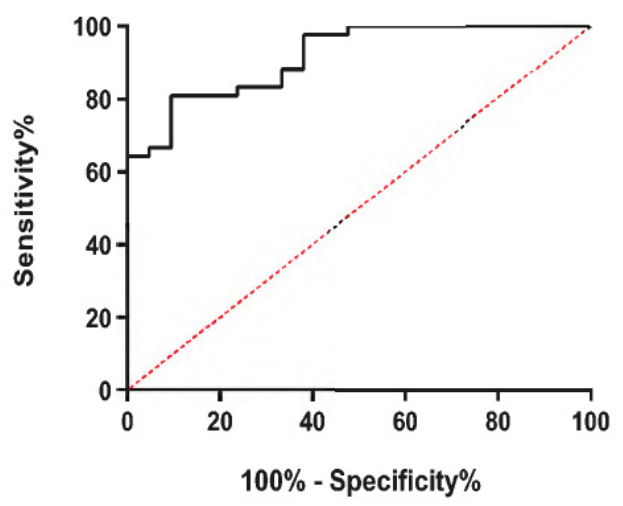

Figure 1. Increased ENPP2 mRNA expression in nasopharyngeal swab samples from patients with mild or severe/critical COVID-19. (A) ENPP2 mRNA values (mean $2^{-\Delta \Delta C t}$ ) from the two groups of patients $(n=21)$ and the control group $(n=21)$. The horizontal dotted line indicates the optimal threshold value (cut-off). Data are represented as box plots; line in the middle, median; box edges, 25 th to 75 th centiles; whiskers, range of values. $p$ values were calculated with the non-parametric Mann-Whitney $U$ test. (B) ROC curves were generated after merging the results for the two positive groups (mild and severe/critical), and AUC, 95\% CI, $p$ values, and cut-off points with their specificity and sensitivity were calculated. The dotted line (in red) represents perfect chance (positive likelihood ratio $=$ sensitivity $/(1$-specificity $)=1)$. Positive mild versus negative samples: ${ }^{*} p=4 \times 10^{-6}$, positive critical/severe versus negative samples: ${ }^{* *} p=2.92 \times 10^{-7}$.

\subsection{Increased Serum ATX Protein Levels in Severe COVID-19 Patients}

To examine if systemic levels of ATX are possibly increased upon COVID-19, ATX was quantified with an ELISA kit in the serum of COVID-19 patients hospitalized at the Evangelismos University Hospital (Table 2; completely independent from cohort/Table 1). The cohort consisted of both WARD ( $\mathrm{n}=47$; no Dex treatment), as well as of Intensive Care Unit (ICU) patients, which were further separated in patients receiving dexamethasone (Dex) treatment $(n=37)$ or not (NO Dex; $n=32)$. A large proportion of patients suffered from comorbidities and were receiving a variety of medications prior to admission, while COVID-19-targeted treatment included azithromycin, chloroquine, and lopinavir/ritonavir in different combinations per WHO recommendations at that time (Table 2). In comparison with WARD patients, ICU patients were hypoxemic (low ratio of arterial oxygen partial pressure to fractional inspired oxygen; $\mathrm{PaO}_{2} / \mathrm{FiO}_{2}$ ), lymphopenic (low lymphocyte numbers), and had increased LDH levels (Table 2), all three suggested as disease severity markers. 
Table 2. Clinical characteristics and laboratory data of COVID-19 patients hospitalized at the Evangelismos general hospital.

\begin{tabular}{|c|c|c|c|}
\hline & WARD No Dex & ICU No Dex & ICU + Dex \\
\hline Number of patients (n) & 47 & 37 & 32 \\
\hline $\operatorname{ATX}(\mathrm{ng} / \mathrm{mL}$, mean $\pm \mathrm{SD})$ & $310.32 \pm 98.85^{*}$ & $443 \pm 172.90$ & $246.15 \pm 73.74^{*}$ \\
\hline \multicolumn{4}{|l|}{ Sex } \\
\hline Male & $33(70.21 \%)$ & $31(83.78 \%)$ & $22(62.5 \%)$ \\
\hline Female & $14(29.78 \%)$ & $6(16.21 \%)$ & $10(31.25 \%)$ \\
\hline Age (years, mean \pm SD) & $54.63 \pm 15.46$ & $63.54 \pm 10.89$ & $65.5 \pm 10.7$ \\
\hline \multicolumn{4}{|l|}{ Comorbidities n (\%) } \\
\hline Hypertension & $13(27.65 \%)$ & $17(45.94 \%)$ & $12(37.5 \%)$ \\
\hline Diabetes & $4(8.51 \%)$ & $5(13.51 \%)$ & $5(15.62 \%)$ \\
\hline Coronary artery disease & $8(17.02 \%)$ & $4(10.81 \%)$ & $4(12.5 \%)$ \\
\hline COPD & $1(2.12 \%)$ & $1(2.7 \%)$ & $2(6.25 \%)$ \\
\hline Asthma & $2(4.25 \%)$ & $1(2.7 \%)$ & $1(3.12 \%)$ \\
\hline Hyperlipidemia & $9(19.14 \%)$ & $9(24.32 \%)$ & $8(25 \%)$ \\
\hline Hepatitis & $0(0 \%)$ & $1(2.7 \%)$ & $0(0 \%)$ \\
\hline COVID-19 treatment & 0 & 11 & \\
\hline Azithromycin/chloroquine/lopinavir/ritonavir & 6 & 7 & \\
\hline Azithromycin/chloroquine & 0 & 2 & \\
\hline Lopinavir/ritonavir/chloroquine & 0 & 3 & \\
\hline Chloroquine Plasma & 0 & 1 & \\
\hline \multicolumn{4}{|l|}{ Clinical measurements } \\
\hline Mean arterial pressure $(\mathrm{mmHg})$ & $83.19 \pm 8.86$ & $82.83 \pm 16.52$ & $77.55 \pm 8.54$ \\
\hline $\mathrm{PaO} 2 / \mathrm{FiO} 2(\mathrm{mmHg})$ & $301.5 \pm 79.81$ * & $194.86 \pm 86.64$ & $85.94 \pm 15.97$ * \\
\hline Glucose $(\mathrm{mg} / \mathrm{dL})$ & $133.5 \pm 113.3$ & $164.53 \pm 77.73$ & $164.06 \pm 75.40$ \\
\hline Creatinine $(\mathrm{mg} / \mathrm{dL})$ & $0.9 \pm 0.33$ & $1.02 \pm 0.32$ & $0.95 \pm 0.72$ \\
\hline CRP (mg/dL) & $6.8 \pm 8.96$ & $14 \pm 10.17$ & $13.83 \pm 9.6$ \\
\hline Total bilirubin (mg/dL) & $0.5 \pm 0.33$ & $0.73 \pm 0.5$ & $0.61 \pm 0.29$ \\
\hline White blood cell count (per $\mu \mathrm{L}$ ) & $6995 \pm 3468$ & $10,125 \pm 4633$ & $11,705 \pm 10,372$ \\
\hline Neutrophils (\%) & $69.34 \pm 13.51$ & $81.34 \pm 6.64$ & $83.12 \pm 12.2$ \\
\hline Lymphocytes (\%) & $24.03 \pm 10.89 *$ & $12.63 \pm 5.63$ & $11.12 \pm 11.23$ \\
\hline Platelets (per $\mu \mathrm{L})$ & $240,297 \pm 110,028$ & $237,783 \pm 101,338$ & $257,000 \pm 79,581$ \\
\hline INR (median IQR) & $1.06 \pm 0.09$ & $2.07 \pm 5.73$ & $1.26 \pm 0.65$ \\
\hline D-dimer $(\mathrm{pg} / \mathrm{mL})$ & $1.19 \pm 1.72$ & $0.47 \pm 0.26$ & $1.39 \pm 0.93$ \\
\hline AST (IU/L) & $36.65 \pm 30.65$ & $54.18 \pm 39.95$ & $121.4 \pm 329.9$ \\
\hline ALT (IU/L) & $33.15 \pm 23.58$ & $45.9 \pm 28.08$ & $60.8 \pm 72.4$ \\
\hline LDH (U/L) & $286.36 \pm 122.08 *$ & $498.48 \pm 242.34$ & $591.23 \pm 490.84$ \\
\hline Fibrinogen (mg/dL) & $514.06 \pm 176.18$ & $638.18 \pm 158.76$ & $630.3 \pm 172.2$ \\
\hline Ferritin $(\mathrm{pg} / \mathrm{mL})$ & $513.48 \pm 815.55$ & $2786 \pm 694.48$ & $912.47 \pm 826.91$ \\
\hline APACHE II score & $5.25 \pm 2.94$ & $14.27 \pm 5.08$ & $15.4 \pm 3.89$ \\
\hline SOFA score & $2 \pm 1$ & $6.83 \pm 3.08$ & $5.4 \pm 1.81$ \\
\hline
\end{tabular}

Statistical significance with ICU NO Dex group values was assessed with one-way ANOVA followed by Bonferroni post hoc correction; * denotes $p<0.0001$. ATX values appear at Figures 2, 3, S1 and S2.

Increased ATX serum concentrations were discovered in ICU patients (not receiving Dex) as compared with WARD patients (Figure 2A), suggesting a possible association of ATX with disease severity. However, no substantial, statistically significant correlation was observed independently with the applicable severity markers (data not shown and Table 2); no statistically significant differences of ATX levels between the sex or the comorbidities of COVID-19 patients was detected (Figure S1). 
A

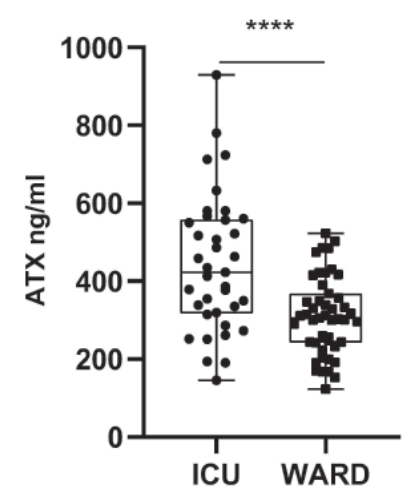

B

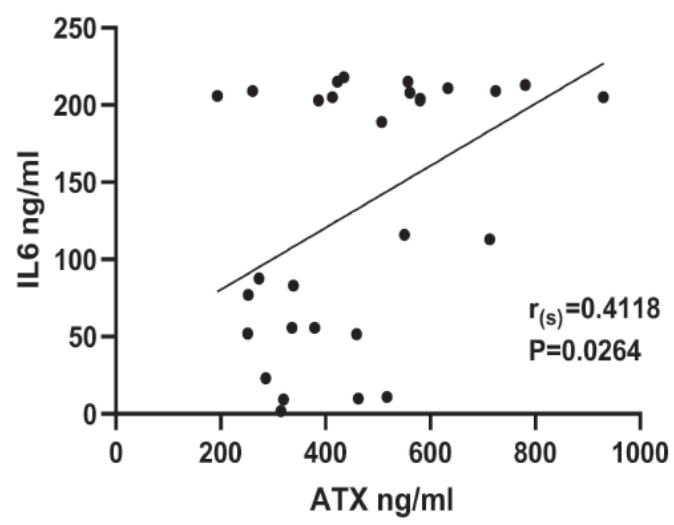

Figure 2. Increased serum ATX protein levels in COVID-19 patients hospitalized in the intensive care unit (ICU), correlating with increased IL-6 levels. (A) ATX protein levels were measured with a commercial ELISA kit in the sera of COVID-19 patients hospitalized (without Dex treatment) in the COVID-19 Ward $(n=47)$ or the ICU $(n=37)$ of the Evangelismos hospital. Statistical significance, given the normal distribution of values, was assessed with an unpaired $t$-test. ${ }^{* * * *}$ denotes $p<0.0001$. (B) ATX serum levels correlated with serum IL-6 levels $(n=29)$, as assessed with Spearman correlation $\left(\mathrm{r}_{(\mathrm{s})}\right)$.

Among the different cytokines that have been reported, with great variance, to get elevated in the COVID-19-induced cytokine storm, IL-6 was found to be the most predictive one $[29,30]$, while in this cohort only IL-6 could be detected in high amounts; the IL-6 levels in some patients reached the upper detection threshold (Figure 2B). Moreover, IL-6 has been reported to stimulate ATX expression in different contexts [31,32]. Therefore, we next examined if ATX and IL-6 serum levels correlate, to discover if, most importantly, ATX levels correlated significantly with IL-6 levels in the serum of ICU patients (not receiving Dex) (Figure 2B), suggesting a possible interplay of ATX/LPA with the cytokine storm in COVID-19.

ICU non-survivors in this cohort had higher levels of the endothelial dysfunction markers soluble E-selectin (sE-sel), soluble P-selectin (sP-sel), soluble intercellular adhesion molecule 1 (sICAM-1), and angiopoietin 2 (ANG-2) when compared to survivors, as recently reported using a subset of the current Evangelismos cohort samples [33]. Interestingly, the increased ATX protein levels correlated with the increased protein levels of sE-sel and sICAM (Figure S2) in ICU patients, suggesting a role for ATX/LPA in COVID-19-induced endothelial dysfunction.

\subsection{Dex Therapeutic Effects in COVID-19 Include the Suppression of ATX Serum Levels}

The first line of therapy for many inflammatory diseases as well as respiratory infections is Dex, which lowers the expression of pro-inflammatory cytokines including IL-6, and which has been proven effective in COVID-19 patients requiring, invasive or not, oxygenation $[34,35]$. Therefore, we next examined ATX serum levels in intubated, or not, ICU patients receiving, or not, Dex treatment. Remarkably, Dex treatment was discovered to potently suppress ATX serum levels in ventilated patients (Figure 3A), while intubated ICU patients receiving no Dex presented with the highest overall ATX serum levels. Identical results were obtained in another cohort of ICU patients from the University hospital of Patras (Table 3) (Figure 3B), indicating that the therapeutic benefits of Dex include the suppression of ATX serum levels. 


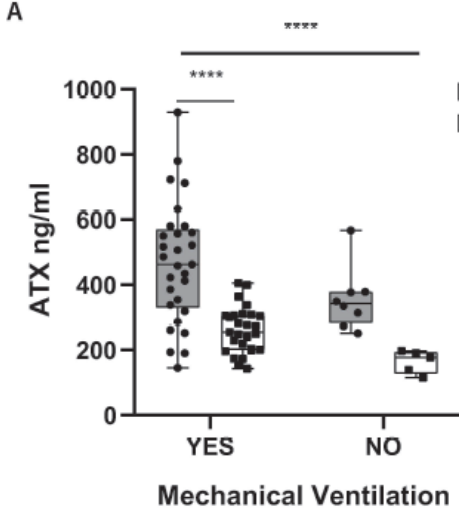

C

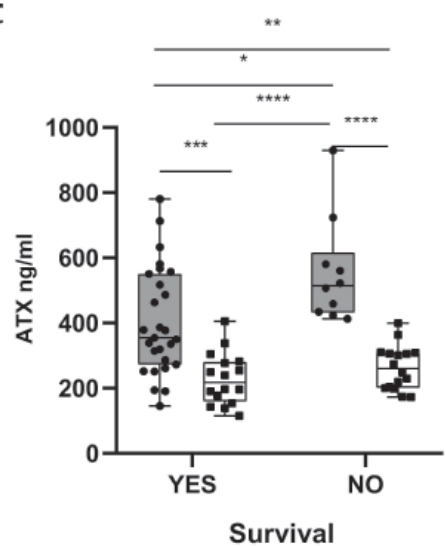

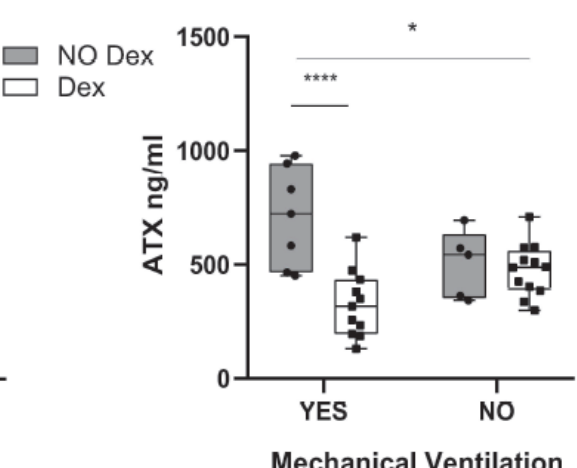

D

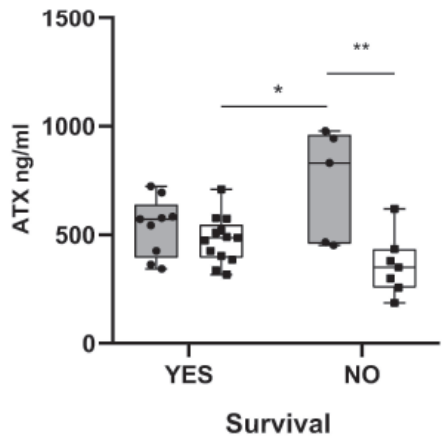

Figure 3. Dexamethasone therapeutic effects include the suppression of ATX serum levels. ATX protein levels were measured, with a commercial ELISA kit in the serum of COVID-19 patients hospitalized in the ICU of $(\mathbf{A}, \mathbf{C})$ the Evangelismos or $(\mathbf{B}, \mathbf{D})$ the Patras hospital. The measurements in the Dex groups in 3A and C, are the same as in Figure 2A. Statistical significance, given the normal distribution of values, was assessed with 2-way ANOVA followed by Bonferroni post hoc correction. $*, * * * * * * * *$ denote $p<0.05, p<0.01, p<0.001$ and $p<0.0001$, respectively.

Table 3. Clinical characteristics and laboratory data of COVID-19 patients hospitalized at the ICU of the University Hospital of Patras.

\begin{tabular}{lcc}
\hline & ICU No Dex & ICU + Dex \\
\hline Number of patients (n) & 12 & 23 \\
\hline ATX $(\mathrm{ng} / \mathrm{mL}$, mean $\pm \mathrm{SD})$ & $624.36 \pm 203.5$ & $\mathbf{4 0 4 . 1 6} \pm \mathbf{1 4 5 . 5 * *}$ \\
\hline Sex & & \\
Male & $9(75 \%)$ & $18(78.26 \%)$ \\
Female & $3(25 \%)$ & $5(21.73 \%)$ \\
\hline Age $($ years, mean $\pm \mathrm{SD})$ & $66.75 \pm 13.31$ & $59.43 \pm 15.42$ \\
\hline Comorbidities $\mathrm{n}(\%)$ & & \\
Hypertension & $5(41.6 \%)$ & $10(43.47 \%)$ \\
Diabetes & $0(0 \%)$ & $4(17.39 \%)$ \\
Coronary artery disease & $2(16.6 \%)$ & $1(4.34 \%)$ \\
COPD & $0(0 \%)$ & $2(8.69 \%)$ \\
Asthma & $0(0 \%)$ & $0(0 \%)$ \\
Hyperlipidemia & $3(25 \%)$ & $6(26.08 \%)$ \\
\end{tabular}


Table 3. Cont.

\begin{tabular}{lcc}
\hline & ICU No Dex & ICU + Dex \\
\hline COVID 19 treatment & & $0(0 \%)$ \\
\hline Azithromycin/chloroquine/lopinavir/ritonavir & $4(33.33 \%)$ & $5(21.73 \%)$ \\
Azithromycin/chloroquine & $6(50 \%)$ & $0(0 \%)$ \\
Lopinavir/ritonavir/chloroquine & $1(8.33 \%)$ & $0(\%)$ \\
Chloroquine & $0(\%)$ & $0(\%)$ \\
Plasma & $0(\%)$ & \\
\hline Clinical measurements & & $\mathbf{1 5 4 . 0 4} \pm \mathbf{4 7 . 9 8 *}$ \\
Glucose (mg/dL) & $120.5 \pm 24.57$ & $0.93 \pm 0.38$ \\
Creatinine (mg/dL) & $0.95 \pm 0.42$ & $15.55 \pm 12.68$ \\
CRP (mg/dL) & $8.53 \pm 5.51$ & $0.7 \pm 0.36$ \\
Total bilirubin (mg/dL) & $0.67 \pm 0.27$ & $0.83 \pm 0.5$ \\
Lymphocytes (absolute number) & $0.62 \pm 0.35$ & $1.07 \pm 0.12$ \\
INR (median IQR) & $1.09 \pm 0.13$ & $1.45 \pm 1.72$ \\
D-dimer (pg/mL) & $2.21 \pm 2.14$ & $455.08 \pm 188.56$ \\
LDH (U/L) & $370 \pm 129$ & $545 \pm 182.32$ \\
Fibrinogen (mg/dL) & $630.55 \pm 168.1$ & $1131.09 \pm 1223.55$ \\
Ferritin (pg/mL) & $950 \pm 382.64$ & \\
\hline
\end{tabular}

Statistical significance was assessed with an unpaired $t$-test; ${ }^{*},{ }^{* *}$ denotes $p<0.05, p<0.01$. ATX values appear in Figure 3.

Moreover, ATX levels in ICU patients not receiving Dex treatment negatively affected survival, and non-surviving ICU patients receiving no Dex presented with the higher overall ATX serum levels (Figure 3C,D).

\subsection{The ENPP2 Expression Landscape in COVID-19}

To identify possible ATX expressing cells in the nasopharyngeal swab (NS) samples (Figure 1), peripheral blood monocytes (PBMCs) in the circulation (Figures 2 and 3), as well as in BALF and lung tissue cells, we re-analyzed and mined several scRNAseq datasets of COVID-19 patients and healthy controls, from recent high impact studies (Table 1), collectively interrogating the gene expression of more than $10^{6}$ cells; cell clustering and naming followed that of the original analyses, which both varied between studies/datasets.

In NS cells, ATX was found to be mainly expressed by natural killer cells (NKs) and monocyte-derived macrophages (MoAM) (Figures 4A and S3A), as detected in two NS datasets (Table 1). In the circulation, and in both PBMCs datasets (Table 1), ENPP2 expression was mainly detected, remarkably, in plasmacytoid DCs (pDCs; Figures 4B and S3B). In BALF cells (Table 1), ENPP2 expression was also mainly detected in pDCs, as well as MoAMs (Figure 4C and Figure S3C). In lung tissue (Table 1), ENPP2 was found to be primarily expressed in arterial and mesothelial cells, as well as in cells of the monocytic lineage (Figure 4D and Figure S3D). A similar lung tissue profile was also detected (Figure S3E) in an IPF scRNAseq dataset (Table 1), extending the similarities of pathogenic mechanisms between IPF and COVID-19 and supporting a common role for ATX. 
A
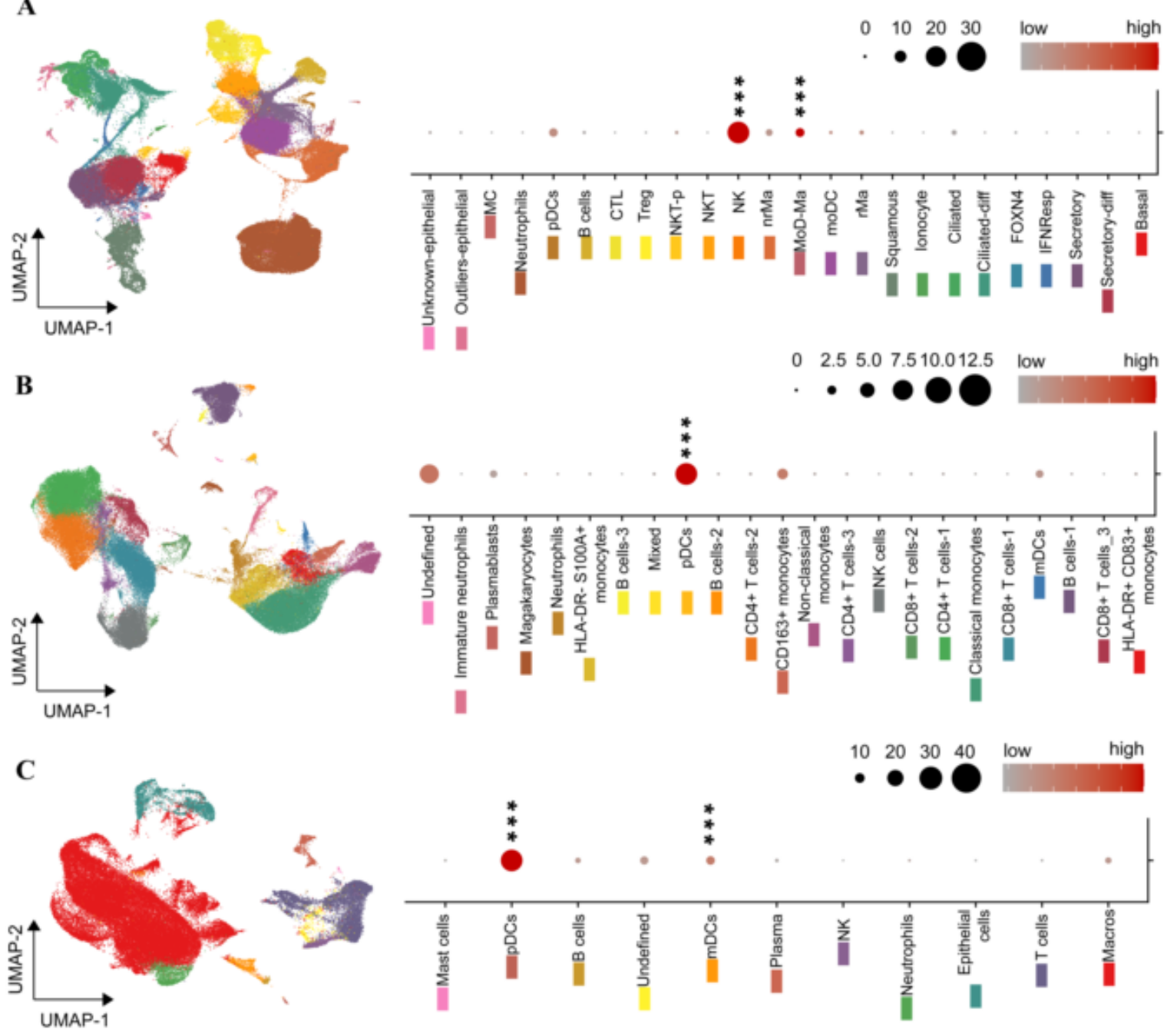

D

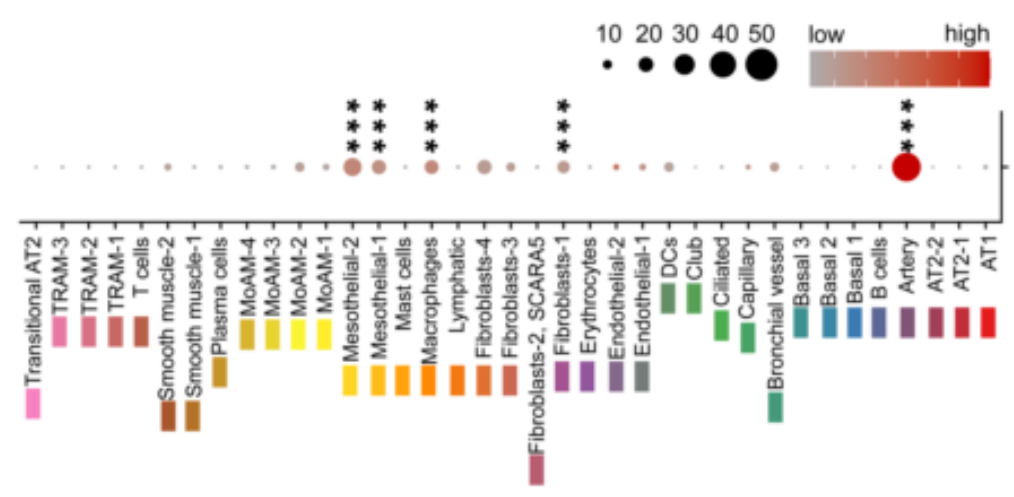

Figure 4. The ENPP2 expression landscape in COVID-19. ENPP2 expression was assessed in four datasets of COVID19/healthy control datasets, each representing a different sampling site ((A) nasopharyngeal swabs; (B) PBMC; (C) BALF; (D) lung tissue; Table 1). UMAP plots (on the left) depict the cellular composition of these sites, while dot plots (on the right) the expression pattern of ENPP2 in the detected cell types. Dot plots cell type color coding refers to that of the respective UMAP. Marker genes, denoted by stars, were detected using a Wilcoxon rank sum test; FC $>1.2$, Bonferroni corrected $p<0.05$; ${ }^{* * *}$ denotes $p<0.01$ (PMIDs: (A) 32591762; (B) 32810438; (C) 32398875; (D) 33257409; Table S1).

\subsection{A Role for ATX in the Homeostasis of Dendritic Cells?}

Given the ENPP2 expression from monocytic cells and especially pDCs, we next interrogated ENNP2 mRNA levels specifically in pDCs from COVID-19 patients in comparison with control samples, subsets of the datasets analyzed in Figure 4. Confined by the 
limited numbers of lung pDCs, as well as the detected genes per cell and the relatively low expression levels of ENPP2, the analysis indicated a statistically significant overexpression of ENPP2 in COVID-19 circulating pDCs (Figure 5B). Noteworthily, DCs are the highest ENPP2 expressing immune cells during healthy conditions, as identified upon querying a large-scale RNAseq dataset interrogating gene expression of 28 immune cell types (79 healthy volunteers and 337 patients from 10 immune-related diseases) [36] (Figure S4A). Similar analysis indicated that the main LPA receptor expressed by DCs, among the at least six LPA receptors reported thus far [37], is LPAR2 (Figure S4B), which has been suggested to convey anti-inflammatory LPA signals to DCs [38]. Furthermore, increased ENPP2 mRNA expression was detected in $\mathrm{pDC}$ from patients with systemic lupus erythematosus (SLE), adult-onset Still's disease (AOSD), mixed connective tissue disease (MCTD), and idiopathic inflammatory myopathy (IIM) than in DCs from healthy volunteers (Figure $\mathrm{S} 4 \mathrm{C}$ ), suggesting that overexpression of ENPP2 in pDCs may be a common theme in inflammation.
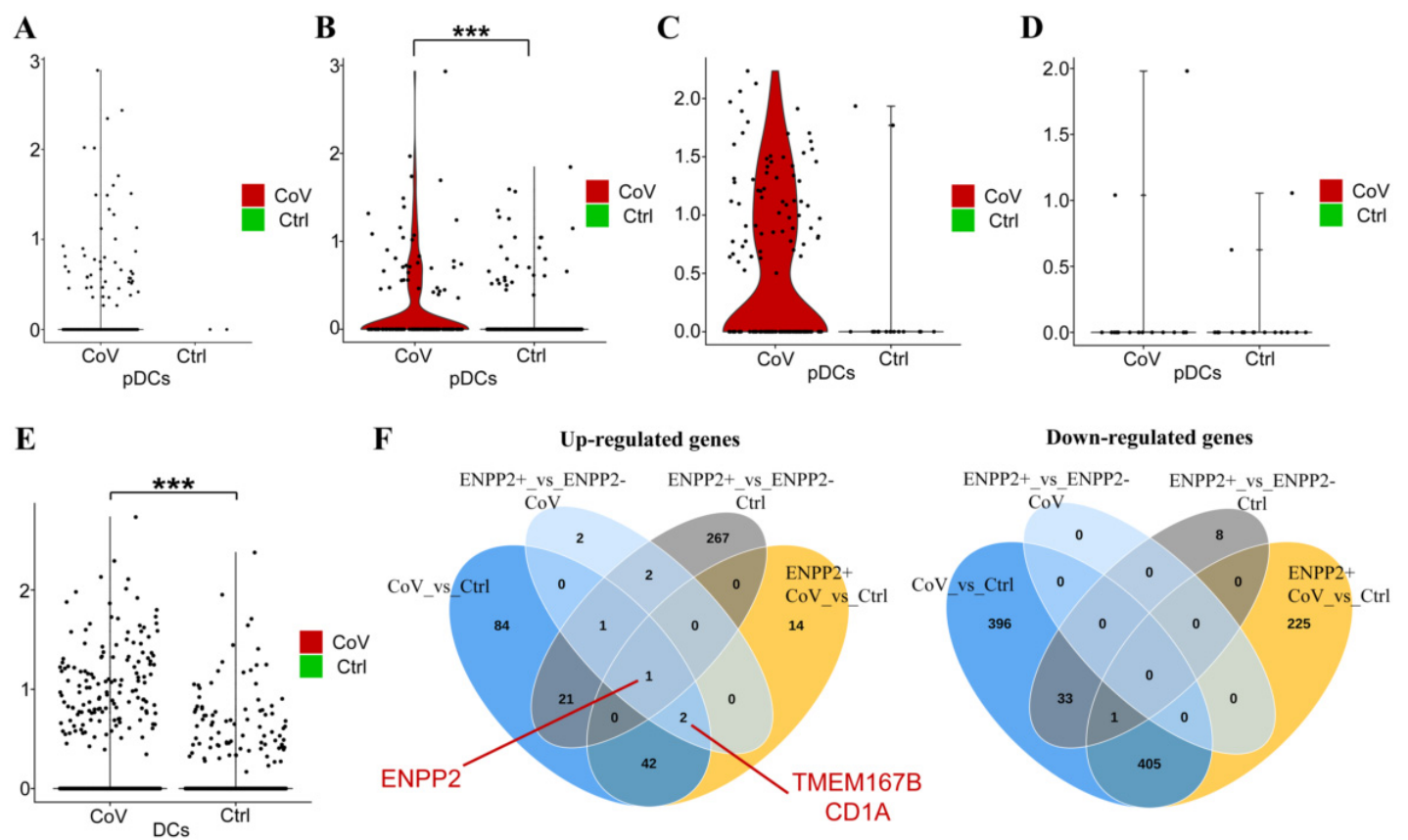

Figure 5. ENPP2 mRNA expression is upregulated in peripheral pDCs and lung tissue DCs of COVID-19 patients. (A-D) Differential expression of ENPP2 in pDCs of COVID-19 patients versus healthy controls: (A) nasopharyngeal swabs; (B) PBMC; (C) BALF; (D) lung tissue. ENPP2 mRNA expression was found up-regulated in peripheral (B) pDCs of COVID-19 patients. (E) Differential expression analysis indicates increased ENPP2 mRNA expression in COVID-19 lung tissue DCs compared to healthy controls. (F) Venn diagrams of deregulated genes in lung DCs. Differential expression was performed using a Wilcoxon rank sum test; FC $>1.2$ and Bonferroni corrected $p<0.05$; ${ }^{* *}$ denotes Bonferroni adjusted p < 0.01. (PMIDs: (A) 32591762; (B) 32810438; (C) 32398875; (D) 33257409; Table S1).

Finally, and to gain mechanistic insights into the possible role of ATX in DC homeostasis upon COVID-19, we first analyzed differential gene expression in COVID-19 DCs (as pDCs were too few), from the only COVID-19 lung dataset [13] allowing such analysis, as well as in ENPP2-expressing (ENPP2 ${ }^{+}$) DCs (Table S5). Increased ENPP2 expression was also detected in all lung DCs (Figure 5E), while comparative analysis (Venn diagrams Figure 5F) highlighted two genes upregulated in ENPP2 ${ }^{+}$COVID-19 DCs, transmembrane protein 176B (TMEM176B) and CD1a, that have been both proposed as DC differentiation and/or maturation markers [39-43], suggesting that ENPP2 expression may modulate DC homeostasis. 


\section{Discussion}

Previous studies have shown that HCV, HIV, and HBV viruses increase Enpp2 mRNA expression in infected cells and/or raise systemic ATX levels [27,44,45]. As shown here, increased ENPP2 mRNA expression was detected in nasopharyngeal swab samples from COVID-19 patients in comparison to non-infected healthy controls (Figure 1), while scRNAseq re-analysis revealed that the highest ENPP2 expressing cells in swabs are immune cells (Figures 5A and S5A), suggesting that CoV-2 infection stimulates ENPP2 expression from immune cells in the nasopharynx. LPA, the enzymatic product of ATX and its effector molecule, has been shown to directly affect $\mathrm{HCV}$ viral infection and replication $[27,28]$, suggesting that a similar autocrine mode of action may be in play in COVID-19, where ATX produced by the infected host cell would stimulate local LPA production, in turn facilitating viral entry and replication.

Increased serum ATX protein have been reported in cancer, liver diseases, as well as respiratory diseases including asthma and pulmonary fibrosis $[19,46]$, while increased levels of serum ATX were recently reported in ARDS [47]. Here, increased ATX sera levels were detected in ICU-hospitalized COVID-19 patients (receiving no Dex treatment) compared to patients with less severe disease (Figure 2), suggesting increased ATX expression as an additional commonality of ARDS and COVID-19.

Several studies have indicated a deregulated serum lipid profile of COVID-19 patients, mainly focusing on fatty acids and triglycerides (reviewed in [48]); however, little is known on phospholipid homeostasis upon CoV-2 infection. As ATX is largely responsible for extracellular LPA synthesis, it would be complementary to quantify LPA levels in the same samples of this study. However, the analyzed serum samples cannot be used because blot clotting and platelet activation stimulate massive LPA release [49]. Moreover, all samples should have been collected in siliconized tubes, to avoid the known attachment of lipids to tubing, and kept at $-80^{\circ} \mathrm{C}$ or lower without repeated freeze thawing [48]. Therefore, a new, multi-controlled, perspective study will be necessary to assess the levels of the different LPA species, as well as related phospholipids, such as LPC, LPE, LPS, and S1P, with whom LPA shares common interconnected biosynthetic pathways.

The origin of serum ATX is not completely deciphered; however, $>40 \%$ of mouse serum constitutively active ATX has been suggested to originate from the adipose tissue [50], which was shown to be able to modulate the pathophysiology of distant metabolically active organs [51,52]. Moreover, serum ATX has been reported to correlate with insulin resistance in older humans with obesity [53], while mice with heterozygous Enpp2 deficiency were protected from HFD-induced obesity and systemic insulin resistance [52]. Several additional reports have incriminated the ATX/LPA axis in the regulation of glucose homeostasis and insulin resistance (reviewed in [54]), among the main comorbidities of COVID-19, suggesting adipose tissue-derived ATX as a possible pathologic link between obesity and COVID-19. No correlation of ATX serum levels with the related underlying comorbidities of COVID-19 patients, cardiovascular diseases, diabetes, and dyslipidemia (Figure S1B) or the body mass index (BMI; data not shown) of patients was observed. However, the lack of correlation could be due to the heterogeneity and size of the examined cohorts, as well as due to the corresponding treatments the patients were receiving for their underlying pathologic conditions prior to $\mathrm{CoV}-2$ infection and hospitalization. In particular, several reports have associated dyslipidemia with increased severity and mortality of COVID-19 (reviewed in [55]), which led to suggestions for lipid-lowering therapies of COVID-19 patients [56], including the administration of statins [57], that inhibit HMGCoA reductase-a rate-limiting enzyme for cholesterol synthesis, to COVID-19 patients. However, results from clinical trials have been controversial [58-60], and larger studies are needed to reach safe conclusions. Interestingly, statins have been reported to inhibit LPA effects on RhoA activation [61], as well as the proliferation of smooth muscle cells and MCP-1 expression via Rac1 [62].

An additional possible source of serum ATX in disease states, beyond the adipose tissue, is the liver. Increased ATX expression has been reported in chronic liver diseases of 
different etiologies, associated with shorter overall survival [27], while the genetic deletion of ATX from hepatocytes [27], or as discussed above adipocytes [51], attenuated liver steatosis and fibrosis. Therefore, increased levels of serum ATX are expected upon liver damage, whereas aberrant liver functions have been reported in COVID-19, irrespectively of pre-existing liver disease [63]. On the other hand, cirrhotic patients have high rates of liver failure and death from respiratory failure upon CoV-2 infection, attributed to increased systemic inflammation, immune dysfunction, and vasculopathy [63]. Therefore, ATX could be also a pathologic link between liver damage and COVID-19.

Plasma ATX levels have been recently reported to correlate with IL-6 levels in severe ARDS patients [47], as well as acute-on-chronic liver failure (ACLF) patients [64], as shown here in the serum of ICU COVID-19 patients (Figure 2). Increased serum IL-6 levels have been reported in COVID-19 patients, correlating with the severity of COVID-19 pneumonia and mortality risk [65], or respiratory failure and the need for mechanical ventilation [66]. Meta-analyses of published studies on COVID-19 laboratory findings indicated that serum levels of IL-6 were among the most predictive biomarkers [29,30]. Interestingly, components of the COVID-19 cytokine storm (IL-6, TNF, and IL-1 $\beta$ ) have been suggested to stimulate ATX expression and/or activity in different cell types, while, vice versa, LPA has been reported to stimulate TNF and IL-6 expression in different contexts [22], suggesting a possible interplay of the COVID-19 cytokine storm and the ATX/LPA axis.

Dex treatment, a potent suppressor of systemic inflammation including IL-6, has been shown to reduce mortality in hospitalized COVID-19 patients under oxygen supplementation treatment or mechanical ventilation $[34,35]$. Dex treatment has been shown to decrease ATX (as well as IL-6) levels in the mouse adipose tissue and plasma [67], as well as in irradiated mammary fat pad [68]. As shown here (Figure 3), Dex treatment of mechanically ventilated patients drastically reduced their ATX serum levels, indicating that the therapeutic effects of Dex in COVID-19 include the suppression of ATX serum levels.

An essential role for ATX/LPA in embryonic vasculature has been well established through genetic studies in both mice [69-71] and zebrafish [72]. In adult mice, ENPP2 has been discovered as a high priority candidate gene for pulmonary hemorrhage upon SARS/MERS-CoV infection [73,74], while vascular leak has been suggested to be among the main pathological effects of ATX/LPA in pulmonary pathophysiology and fibrosis in mice [21,22]. As shown here, ENPP2 mRNA expression in the COVID-19 lung tissue was detected mainly in artery cells D and Figure S3D), while high ATX expression from ECs in HEVs in lymph nodes has been previously reported [75]. Moreover, and in the same context, a plethora of LPA in vitro effects on endothelial cells has been suggested, with some controversy, including endothelial permeability, leukocyte adhesion, and cytokine expression, as previously reported in detail [26]. Among them, LPA has been suggested to stimulate the expression of E-sel from human aortic endothelial cells [76-78], a cell surface adhesion molecule regulating interaction with leukocytes. As shown here, ATX serum levels correlated with the corresponding sE-sel and sICAM serum levels (Figure S2), which has been independently associated, in the same samples, with mortality of COVID-19 ICU patients [33], suggesting that ATX/LPA effects in COVID-19 may also include vasculopathy.

IPF macrophages have been previously shown to stain for ATX, and conditional genetic deletion of ATX from macrophages (LysM ${ }^{+}$cells) in mice, reduced BALF ATX levels and disease severity in modeled pulmonary fibrosis [20]. scRNAseq analysis of BALF cells from COVID-19 patients, where macrophages predominate, indicated that ENPP2 mRNA expression was detected in different macrophage subpopulations (Figure 4C/UMAP, S3C/UMAP), pending FACS validation, where it could modulate their maturation in an autocrine mode via LPA [79-81]. LPA has also been suggested to stimulate, in vitro, the conversion of monocytes to DCs $[38,82,83]$. Interestingly, ENPP2 mRNA expression was mainly detected in pDCs among all PBMCs and BALF cells in COVID-19 (Figure $4 \mathrm{~B}, \mathrm{C}$ and Figure S3B,C). pDCs are the principal interferon (IFN) type I producing cells in the human blood and can be rapidly recruited to inflamed sites [84]. Circulating 
and lung pDCs have been shown to be diminished in COVID-19 [85,86], while IFN type I responses were highly impaired $[87,88]$. ENPP2 mRNA expression was found upregulated in circulating pDCs (Figure 5B), and lung DCs (Figure 5E) from COVID-19 patients in comparison to cells from healthy controls. pDC development and homeostasis are regulated by the transcription TCF4 [89], which has been reported to be modulated by LPA in colon cancer cells [90], suggesting that ENPP2 expression from pDCs and the local production of LPA modulates, in an autocrine manner, pDC development and homeostasis. The hypothesis is further supported from the genes that have been discovered, pending validation, to be increased in COVID-19 DCs, possibly regulated by ENPP2 (Figure 5E). CD1a binds and presents to T-cell lipid metabolites and PLA2-synthesised fatty acid neoantigens and has been found to be expressed in immature DCs in mucosal surfaces, including the bronchus [39-41]. Tmem176B has also been associated with an immature state of dendritic cells [42,43], suggesting that ENPP2 expression from COVID-19 pDCs, via LPA, delays their maturation. Although LPA signals in most cell types are considered pro-inflammatory and pro-surviving, an anti-inflammatory role of LPA, via LPAR2 - the main subtype expressed in DCs (Figure S4B), has been proposed previously for DCs [38], further supporting a possible role for ATX/LPA in suppressing DC responses.

Taken together, a role for ATX/LPA in COVID-19 pathogenesis seems likely, possibly as a component of the cytokine storm perpetuating hyperinflammation and stimulating endothelial damage, as well as a regulator of the mononuclear phagocyte system and a suppressor of (p)DCs responses, non-withstanding its established role in fibrosis. Dex treatment in mechanically ventilated patients decreased ATX levels, indicating that the therapeutic effects of Dex in COVID-19 include the suppression of the ATX/LPA axis and that ATX levels can be druggable. More importantly, and given that COVID-19 and IPF share risk factors for disease severity, such as age/sex and comorbidities, existing and developing anti-fibrotic therapies have been suggested as additional therapeutic opportunities in COVID-19 [91-93]. One of the novel candidates target ATX is currently in clinical trials phase III in IPF [25]. Given the multiple possible roles of ATX in COVID-19, ATX inhibition could offer additional therapeutic options in COVID-19 management, both during and after hospitalization.

\section{Materials and Methods}

\subsection{Human Patients and Samples}

All studies were performed in accordance with the Helsinki Declaration principles. All collected data were anonymized in standardized forms, and informed consent was obtained from all individuals or patients' next-of-kin for severe cases. All available patient personal, epidemiological, clinical, and experimental data are summarized in the corresponding cohorts (Tables 1-3). All three cohorts were completely independent, and there was no overlap between swab and blood samples.

Cohort 1: Nasopharyngeal swab (NS) samples were collected upon routine diagnosis from adult patients tested positive in SARS-CoV2 RNA PCR and showing no or mild COVID-19 clinical symptoms, including cough, sore throat, mild fever below $38^{\circ} \mathrm{C}$, and loss of smell (positive mild group) or being hospitalized in the intensive care unit (ICU) with severe/critical symptoms, such as respiratory failure, septic shock, acute thrombosis, and multiorgan dysfunction (positive severe/critical group). The control group consisted of individuals with a negative SARS-CoV2 RNA PCR.

Cohort 2: Serum samples were collected with standardized procedures from COVID19 patients admitted to the specialized COVID-19 WARD or to the intensive care unit (ICU) of the Evangelismos General Hospital from 24 March to 2 November 2020. SARSCoV-2 infection was diagnosed by real-time reverse transcription PCR in nasopharyngeal swabs. The study was approved by the Evangelismos Hospital Research Ethics Committee (\#170/24-4-2020).

Cohort 3: Serum samples were collected with standardized procedures from COVID19 patients admitted to intensive care unit (ICU) of the University Hospital of Patras from 
24 April to 6 December 2020. The study was approved by the University Hospital of Patras Research Ethics Committee (\#216/08-05-2020).

\subsection{Enzyme-Linked Immunosorbent Assay (ELISA)}

ATX and IL-6 protein levels were quantified with dedicated ELISA kits according to the manufacturer's instructions (R\&D Systems Inc., Minneapolis, MN, USA, and Invitrogen, ThermoFisher Scientific, Waltham, MA, USA, respectively). Measurements were performed in a blinded fashion in triplicate using a Triturus automated analyzer (Grifols, Barcelona, Spain). The presented results on ELISA quantification of soluble E-selectin (sE-sel) and Pselectin (sP-sel), ICAM, and ANG2 in the same samples, has been reported previously [33].

\subsection{RNA Extraction and Q-RT-PCR}

Total RNA extraction from nasopharyngeal swab samples was performed using a MagNA Pure LC Total Nucleic Acid Isolation Kit using a MagNa Pure LC 2.0 automated nucleic acid purifier (Roche, Basel, Switzerland), and viral RNA was quantified with a LightMix Modular SARS-CoV-2 RdRP Kit and a LightCycler Multiplex RNA Virus Master kit (Roche, Basel, Switzerland). ENPP2 mRNA levels were quantified with Q-RT-PCR using a SYBR Green-based Luna ${ }^{\circledR}$ Universal qPCR Master Mix (New England Biolabs, Ipswich, MA, USA) (ENPP2: forward: 5'- ACT CAT GAA GAT GCA CAC AGC -3'; reverse $5^{\prime}$ - CGC TCT CAT ATG TAT GCA GG -3'; product length $131 \mathrm{bp}$ ). Normalization was performed with the house-keeping gene 14-3-3-zeta polypeptide (YWHAZ), and the relative quantification method $2^{-\Delta \Delta C t}$ was utilized.

\subsection{Bulk/Single Cell RNA-seq Data Analysis and Mining}

The available single cell RNA-seq object was mined for each one of the datasets (Table 1) using Seurat package v3 [94]. Marker selection and DEA were performed using Wilcoxon Rank Sum test (FC $>1.2$; Bonferroni adj. $p<0.05$ ). For identifying pDCs in the lung dataset of [13], DCs-as initially marked -were isolated, and principal components were calculated post to variable genes identification and data scaling using default parameters. The 30 first principal components were used to construct an SNN graph, while clusters were defined with a resolution of 0.8. pDCs were identified using marker genes reported in the cell atlas of [95].

Preprocessed read count matrices of [36] found here were analyzed using the metaseqR2 package [96]. More specifically, reads were EDASeq normalized, filtered using default parameters, and then the PANDORA algorithm was used to combine the results of DESeq [97], DESeq2 [98], limma-voom [99], edgeR [100], and ABSSeq [101] methods. DEGs were defined using a FC $>1.2$ and FDR adj. meta $p$-value $<0.05$.

\subsection{Statistical Analysis}

Statistical significance was assessed with Prism (GraphPad, San Diego, CA, USA) software with the appropriate test according to the distribution of values and their complexity, as detailed in each figure legend. Statistical tests used include the non-parametric Mann-Whitney U test, unpaired $t$-test, Spearman correlation, 2-way ANOVA followed by Bonferroni post hoc correction, Wilcoxon rank sum test-Bonferroni correction, and Kruskal-Wallis and Dunn post hoc test.

Supplementary Materials: The following are available online at https:/ /www.mdpi.com/article/10 .3390/ijms221810006/s1.

Author Contributions: Conceptualization, V.A.; Data curation, I.N., V.D., A.G.V., E.J., S.T., I.D., K.A. and A.T.; Formal analysis, I.N., D.F., K.N., P.M., G.M., M.E., A.G.V., N.V. and V.A.; Funding acquisition, V.A.; Investigation, I.N., V.D., I.D., E.A., K.A., A.K. and V.A.; Methodology, I.N., G.M., M.E., A.G.V. and N.V.; Project administration, V.A.; Resources, S.E.O., I.D., E.A., K.A., A.T. and A.K.; Software, D.F. and P.M.; Supervision, P.M., S.E.O., I.D., E.A., K.A., N.V., A.T., A.K. and V.A.; 
Visualization, D.F.; Writing-original draft, I.N., D.F., K.N. and N.V.; Writing-review and editing, V.A. All authors have read and agreed to the published version of the manuscript.

Funding: This work has been co-financed by the European Union and Greek national funds through the Operational Program Competitiveness, Entrepreneurship, and Innovation, under the call Research-Create-Innovate (project code: T1EDK-0049; recipient VA). The funders had no role in study design, data collection and analysis, decision to publish, or preparation of the manuscript.

Institutional Review Board Statement: The study was conducted according to the guidelines of the Declaration of Helsinki, and approved by the Research Ethics Committees of Evangelismos Hospital (\#170/24-4-2020) and University Hospital of Patras (\#216/08-05-2020).

Informed Consent Statement: All collected data were anonymized in standardized forms, and informed consent was obtained from all individuals or patients' next-of-kin for severe cases.

Data Availability Statement: All utilized, publicly available, datasets are detailed at Supplementary Table S1.

Acknowledgments: We would like to thank Alexandros Zacharis and Nikolaos Athanasiou for sample collection.

Conflicts of Interest: The authors declare no conflict of interest.

\section{References}

1. Hu, B.; Guo, H.; Zhou, P.; Shi, Z.-L. Characteristics of SARS-CoV-2 and COVID-19. Nat. Rev. Microbiol. 2020, 19, 141-154. [CrossRef]

2. $\quad$ Osuchowski, M.F.; Winkler, M.S.; Skirecki, T.; Cajander, S.; Shankar-Hari, M.; Lachmann, G.; Monneret, G.; Venet, F.; Bauer, M.; Brunkhorst, F.M.; et al. The COVID-19 puzzle: Deciphering pathophysiology and phenotypes of a new disease entity. Lancet Respir. Med. 2021, 9, 622-642. [CrossRef]

3. Huertas, A.; Montani, D.; Savale, L.; Pichon, J.; Tu, L.; Parent, F.; Guignabert, C.; Humbert, M. Endothelial cell dysfunction: A major player in SARS-CoV-2 infection (COVID-19)? Eur. Respir. J. 2020, 56, 2001634. [CrossRef] [PubMed]

4. Fajgenbaum, D.C.; June, C.H. Cytokine Storm. N. Engl. J. Med. 2020, 383, 2255-2273. [CrossRef]

5. Matthay, M.A.; Zemans, R.L.; Zimmerman, G.A.; Arabi, Y.M.; Beitler, J.R.; Mercat, A.; Herridge, M.; Randolph, A.G.; Calfee, C.S. Acute respiratory distress syndrome. Nat. Rev. Dis. Primers 2019, 5, 18. [CrossRef]

6. Burnham, E.L.; Janssen, W.J.; Riches, D.W.; Moss, M.; Downey, G.P. The fibroproliferative response in acute respiratory distress syndrome: Mechanisms and clinical significance. Eur. Respir. J. 2014, 43, 276-285. [CrossRef] [PubMed]

7. Maiese, A.; Manetti, A.C.; La Russa, R.; Di Paolo, M.; Turillazzi, E.; Frati, P.; Fineschi, V. Autopsy findings in COVID-19-related deaths: A literature review. Forensic. Sci. Med. Pathol. 2020, 17, 279-296. [CrossRef] [PubMed]

8. Mo, X.; Jian, W.; Su, Z.; Chen, M.; Peng, H.; Peng, P.; Lei, C.; Chen, R.; Zhong, N.; Li, S. Abnormal pulmonary function in COVID-19 patients at time of hospital discharge. Eur. Respir. J. 2020, 55, 2001217. [CrossRef]

9. Frija-Masson, J.; Debray, M.P.; Gilbert, M.; Lescure, F.X.; Travert, F.; Borie, R.; Khalil, A.; Crestani, B.; d'Ortho, M.P.; Bancal, C. Functional characteristics of patients with SARS-CoV-2 pneumonia at 30 days post-infection. Eur. Respir. J. 2020, 56, 81. [CrossRef] [PubMed]

10. Gassel, R.J.J.; Bels, J.L.M.; Raafs, A.; Bussel, B.C.T.; Poll, M.C.G.; Simons, S.O.; Meer, L.W.L.; Gietema, H.A.; Posthuma, R.; Santen, S. High Prevalence of Pulmonary Sequelae at 3 Months after Hospital Discharge in Mechanically Ventilated Survivors of COVID-19. Am. J. Respir. Crit. Care Med. 2021, 203, 371-374. [CrossRef]

11. George, P.M.; Barratt, S.L.; Condliffe, R.; Desai, S.R.; Devaraj, A.; Forrest, I.; Gibbons, M.A.; Hart, N.; Jenkins, R.G.; McAuley, D.F.; et al. Respiratory follow-up of patients with COVID-19 pneumonia. Thorax 2020, 75, 1009-1016. [CrossRef]

12. Myall, K.J.; Mukherjee, B.; Castanheira, A.M.; Lam, J.L.; Benedetti, G.; Mak, S.M.; Preston, R.; Thillai, M.; Dewar, A.; Molyneaux, P.L.; et al. Persistent Post-COVID-19 Interstitial Lung Disease. An Observational Study of Corticosteroid Treatment. Ann. Am. Thorac. Soc. 2021, 18, 799-806. [CrossRef]

13. Bharat, A.; Querrey, M.; Markov, N.S.; Kim, S.; Kurihara, C.; Garza-Castillon, R.; Manerikar, A.; Shilatifard, A.; Tomic, R.; Politanska, Y.; et al. Lung transplantation for patients with severe COVID-19. Sci. Transl. Med. 2020, 12, eabe4282. [CrossRef]

14. Wu, M.; Chen, Y.; Xia, H.; Wang, C.; Tan, C.Y.; Cai, X.; Liu, Y.; Ji, F.; Xiong, P.; Liu, R.; et al. Transcriptional and proteomic insights into the host response in fatal COVID-19 cases. Proc. Natl. Acad. Sci. USA 2020, 117, 28336-28343. [CrossRef]

15. McDonald, L.T. Healing after COVID-19: Are survivors at risk for pulmonary fibrosis? Am. J. Physiol. Lung Cell. Mol. Physiol. 2021, 320, L257-1265. [CrossRef] [PubMed]

16. Esposito, A.J.; Menon, A.A.; Ghosh, A.J.; Putman, R.K.; Fredenburgh, L.E.; El-Chemaly, S.Y.; Goldberg, H.J.; Baron, R.M.; Hunninghake, G.M.; Doyle, T.J. Increased Odds of Death for Patients with Interstitial Lung Disease and COVID-19: A CaseControl Study. Am. J. Respir. Crit. Care Med. 2020, 202, 1710-1713. [CrossRef] 
17. Drake, T.M.; Docherty, A.B.; Harrison, E.M.; Quint, J.K.; Adamali, H.; Agnew, S.; Babu, S.; Barber, C.M.; Barratt, S.; Bendstrup, E.; et al. Outcome of Hospitalization for COVID-19 in Patients with Interstitial Lung Disease. An International Multicenter Study. Am. J. Respir. Crit. Care Med. 2020, 202, 1656-1665. [CrossRef] [PubMed]

18. Beltramo, G.; Cottenet, J.; Mariet, A.S.; Georges, M.; Piroth, L.; Tubert-Bitter, P.; Bonniaud, P.; Quantin, C. Chronic respiratory diseases are predictors of severe outcome in COVID-19 hospitalised patients: A nationwide study. Eur. Respir. J. 2021, 3, 74. [CrossRef]

19. Magkrioti, C.; Galaris, A.; Kanellopoulou, P.; Stylianaki, E.A.; Kaffe, E.; Aidinis, V. Autotaxin and chronic inflammatory diseases. J. Autoimmun. 2019, 104, 102327. [CrossRef] [PubMed]

20. Oikonomou, N.; Mouratis, M.A.; Tzouvelekis, A.; Kaffe, E.; Valavanis, C.; Vilaras, G.; Karameris, A.; Prestwich, G.D.; Bouros, D.; Aidinis, V. Pulmonary autotaxin expression contributes to the pathogenesis of pulmonary fibrosis. Am. J. Respir. Cell Mol. Biol. 2012, 47, 566-574. [CrossRef]

21. Tager, A.M.; LaCamera, P.; Shea, B.S.; Campanella, G.S.; Selman, M.; Zhao, Z.; Polosukhin, V.; Wain, J.; Karimi-Shah, B.A.; Kim, N.D.; et al. The lysophosphatidic acid receptor LPA1 links pulmonary fibrosis to lung injury by mediating fibroblast recruitment and vascular leak. Nat. Med. 2008, 14, 45-54. [CrossRef]

22. Ninou, I.; Magkrioti, C.; Aidinis, V. Autotaxin in Pathophysiology and Pulmonary Fibrosis. Front. Med. 2018, 5, 180. [CrossRef]

23. Ninou, I.; Kaffe, E.; Muller, S.; Budd, D.C.; Stevenson, C.S.; Ullmer, C.; Aidinis, V. Pharmacologic targeting of the ATX/LPA axis attenuates bleomycin-induced pulmonary fibrosis. Pulm. Pharmacol. Ther. 2018, 52, 32-40. [CrossRef]

24. Tager, A.M. Autotaxin emerges as a therapeutic target for idiopathic pulmonary fibrosis: Limiting fibrosis by limiting lysophosphatidic acid synthesis. Am. J. Respir. Cell Mol. Biol. 2012, 47, 563-565. [CrossRef]

25. Maher, T.M.; Kreuter, M.; Lederer, D.J.; Brown, K.K.; Wuyts, W.; Verbruggen, N.; Stutvoet, S.; Fieuw, A.; Ford, P.; Abi-Saab, W.; et al. Rationale, design and objectives of two phase III, randomised, placebo-controlled studies of GLPG1690, a novel autotaxin inhibitor, in idiopathic pulmonary fibrosis (ISABELA 1 and 2). BMJ Open Respir. Res. 2019, 6, e000422. [CrossRef]

26. Magkrioti, C.; Aidinis, V. ATX and LPA signalling in lung pathophysiology. World J. Respirol. 2013, 3, 77-103. [CrossRef]

27. Kaffe, E.; Katsifa, A.; Xylourgidis, N.; Ninou, I.; Zannikou, M.; Harokopos, V.; Foka, P.; Dimitriadis, A.; Evangelou, K.; Moulas, A.N.; et al. Hepatocyte autotaxin expression promotes liver fibrosis and cancer. Hepatology 2017, 65, 1369-1383. [CrossRef] [PubMed]

28. Farquhar, M.J.; Humphreys, I.S.; Rudge, S.A.; Wilson, G.K.; Bhattacharya, B.; Ciaccia, M.; Hu, K.; Zhang, Q.; Mailly, L.; Reynolds, G.M.; et al. Autotaxin-lysophosphatidic acid receptor signalling regulates hepatitis C virus replication. J. Hepatol. 2017, 9, 16. [CrossRef] [PubMed]

29. Zhang, Z.-L.; Hou, Y.-L.; Li, D.-T.; Li, F.-Z. Laboratory findings of COVID-19: A systematic review and meta-analysis. Scand. J. Clin. Lab. Investig. 2020, 80, 441-447. [CrossRef] [PubMed]

30. Ulhaq, Z.S.; Soraya, G.V. Interleukin-6 as a potential biomarker of COVID-19 progression. Méd. Mal. Infect. 2020, 50, 382-383. [CrossRef]

31. Sun, S.; Wang, R.; Song, J.; Guan, M.; Li, N.; Zhang, X.; Zhao, Z.; Zhang, J. Blocking gp130 signaling suppresses autotaxin expression in adipocytes and improves insulin sensitivity in diet-induced obesity. J. Lipid Res. 2017, 58, 2102-2113. [CrossRef] [PubMed]

32. Castelino, F.V.; Bain, G.; Pace, V.A.; Black, K.E.; George, L.; Probst, C.K.; Goulet, L.; Lafyatis, R.; Tager, A.M. An Autotaxin/Lysophosphatidic Acid/Interleukin-6 Amplification Loop Drives Scleroderma Fibrosis. Arthritis Rheumatol. 2016, 68, 2964-2974. [CrossRef] [PubMed]

33. Vassiliou, A.G.; Keskinidou, C.; Jahaj, E.; Gallos, P.; Dimopoulou, I.; Kotanidou, A.; Orfanos, S.E. ICU Admission Levels of Endothelial Biomarkers as Predictors of Mortality in Critically Ill COVID-19 Patients. Cells 2021, 10, 186. [CrossRef] [PubMed]

34. Horby, P.; Lim, W.S.; Emberson, J.R.; Mafham, M.; Bell, J.L.; Linsell, L.; Staplin, N.; Brightling, C.; Ustianowski, A.; Elmahi, E.; et al. Dexamethasone in Hospitalized Patients with Covid-19. N. Engl. J. Med. 2021, 384, 693-704.

35. Sterne, J.A.C.; Murthy, S.; Diaz, J.V.; Slutsky, A.S.; Villar, J.; Angus, D.C.; Annane, D.; Azevedo, L.C.P.; Berwanger, O.; Cavalcanti, A.B.; et al. Association Between Administration of Systemic Corticosteroids and Mortality Among Critically Ill Patients With COVID-19: A Meta-analysis. JAMA 2020, 324, 1330-1341. [PubMed]

36. Ota, M.; Nagafuchi, Y.; Hatano, H.; Ishigaki, K.; Terao, C.; Takeshima, Y.; Yanaoka, H.; Kobayashi, S.; Okubo, M.; Shirai, H.; et al. Dynamic landscape of immune cell-specific gene regulation in immune-mediated diseases. Cell 2021, 184, 3006-3021.e17. [CrossRef] [PubMed]

37. Yung, Y.C.; Stoddard, N.C.; Chun, J. LPA receptor signaling: Pharmacology, physiology, and pathophysiology. J. Lipid Res. 2014, 55, 1192-1214. [CrossRef]

38. Emo, J.; Meednu, N.; Chapman, T.J.; Rezaee, F.; Balys, M.; Randall, T.; Rangasamy, T.; Georas, S.N. Lpa2 Is a Negative Regulator of Both Dendritic Cell Activation and Murine Models of Allergic Lung Inflammation. J. Immunol. 2012, 188, 3784-3790. [CrossRef] [PubMed]

39. Tazi, A.; Bouchonnet, F.; Grandsaigne, M.; Boumsell, L.; Hance, A.J.; Soler, P. Evidence that granulocyte macrophage-colonystimulating factor regulates the distribution and differentiated state of dendritic cells/Langerhans cells in human lung and lung cancers. J. Clin. Investig. 1993, 91, 566-576. [CrossRef]

40. Zeng, Z.; Castaño, A.R.; Segelke, B.W.; Stura, E.A.; Peterson, P.A.; Wilson, I.A. Crystal structure of mouse CD1: An MHC-like fold with a large hydrophobic binding groove. Science 1997, 277, 339-345. [CrossRef] 
41. Bourgeois, E.A.; Subramaniam, S.; Cheng, T.Y.; De Jong, A.; Layre, E.; Ly, D.; Salimi, M.; Legaspi, A.; Modlin, R.L.; Salio, M.; et al. Bee venom processes human skin lipids for presentation by CD1a. J. Exp. Med. 2015, 212, 149-163. [CrossRef] [PubMed]

42. Condamine, T.; Le Texier, L.; Howie, D.; Lavault, A.; Hill, M.; Halary, F.; Cobbold, S.; Waldmann, H.; Cuturi, M.C.; Chiffoleau, E. Tmem176B and Tmem176A are associated with the immature state of dendritic cells. J. Leukoc. Biol. 2010, 88, 507-515. [CrossRef] [PubMed]

43. Picotto, G.; Morse, L.R.; Nguyen, N.; Saltzman, J.; Battaglino, R. TMEM176A and TMEM176B Are Candidate Regulators of Inhibition of Dendritic Cell Maturation and Function after Chronic Spinal Cord Injury. J. Neurotrauma 2020, 37, 528-533. [CrossRef]

44. Kostadinova, L.; Shive, C.L.; Anthony, D.D. Elevated Autotaxin and LPA Levels During Chronic Viral Hepatitis and Hepatocellular Carcinoma Associate with Systemic Immune Activation. Cancers 2019, 11, 1867. [CrossRef] [PubMed]

45. Joshita, S.; Ichikawa, Y.; Umemura, T.; Usami, Y.; Sugiura, A.; Shibata, S.; Yamazaki, T.; Fujimori, N.; Komatsu, M.; Matsumoto, A.; et al. Serum autotaxin is a useful liver fibrosis marker in patients with chronic hepatitis B virus infection. Hepatol. Res. 2018, 48, 275-285. [CrossRef]

46. Barbayianni, E.; Kaffe, E.; Aidinis, V.; Kokotos, G. Autotaxin, a secreted lysophospholipase D, as a promising therapeutic target in chronic inflammation and cancer. Prog. Lipid Res. 2015, 58, 76-96. [CrossRef]

47. Gao, L.; Li, X.; Wang, H.; Liao, Y.; Zhou, Y.; Wang, K.; Hu, J.; Cheng, M.; Zeng, Z.; Wang, T.; et al. Autotaxin levels in serum and bronchoalveolar lavage fluid are associated with inflammatory and fibrotic biomarkers and the clinical outcome in patients with acute respiratory distress syndrome. J. Intensive Care 2021, 9, 44. [CrossRef]

48. Casari, I.; Manfredi, M.; Metharom, P.; Falasca, M. Dissecting lipid metabolism alterations in SARS-CoV-2. Prog. Lipid Res. 2021, 82, 101092. [CrossRef]

49. Smyth, S.S.; Kraemer, M.; Yang, L.; Van Hoose, P.; Morris, A.J. Roles for lysophosphatidic acid signaling in vascular development and disease. Biochim. Biophys. Acta Mol. Cell Biol. Lipids 2020, 1865, 158734. [CrossRef]

50. Dusaulcy, R.; Rancoule, C.; Gres, S.; Wanecq, E.; Colom, A.; Guigne, C.; van Meeteren, L.A.; Moolenaar, W.H.; Valet, P.; SaulnierBlache, J.S. Adipose-specific disruption of autotaxin enhances nutritional fattening and reduces plasma lysophosphatidic acid. $J$. Lipid Res. 2011, 52, 1247-1255. [CrossRef] [PubMed]

51. Brandon, J.A.; Kraemer, M.; Vandra, J.; Halder, S.; Ubele, M.; Morris, A.J.; Smyth, S.S. Adipose-derived autotaxin regulates inflammation and steatosis associated with diet-induced obesity. PLoS ONE 2019, 14, e0208099. [CrossRef]

52. D'Souza, K.; Nzirorera, C.; Cowie, A.M.; Varghese, G.P.; Trivedi, P.; Eichmann, T.O.; Biswas, D.; Touaibia, M.; Morris, A.J.; Aidinis, V.; et al. Autotaxin-LPA signaling contributes to obesity-induced insulin resistance in muscle and impairs mitochondrial metabolism. J. Lipid Res. 2018, 59, 1805-1817. [CrossRef]

53. Reeves, V.L.; Trybula, J.S.; Wills, R.C.; Goodpaster, B.H.; Dube, J.J.; Kienesberger, P.C.; Kershaw, E.E. Serum Autotaxin/ENPP2 correlates with insulin resistance in older humans with obesity. Obesity 2015, 23, 2371-2376. [CrossRef]

54. D'Souza, K.; Paramel, G.V.; Kienesberger, P.C. Lysophosphatidic Acid Signaling in Obesity and Insulin Resistance. Nutrients 2018, 10, 399. [CrossRef]

55. Liu, Y.; Pan, Y.; Yin, Y.; Chen, W.; Li, X. Association of dyslipidemia with the severity and mortality of coronavirus disease 2019 (COVID-19): A meta-analysis. Virol. J. 2021, 18, 157. [CrossRef]

56. Adam, S.; Ho, J.H.; Bashir, B.; Iqbal, Z.; Ferdousi, M.; Syed, A.A.; Soran, H. The impact of atherosclerotic cardiovascular disease, dyslipidaemia and lipid lowering therapy on Coronavirus disease 2019 outcomes: An examination of the available evidence. Curr. Opin. Lipidol. 2021, 32, 231-243. [CrossRef] [PubMed]

57. Ferrara, F.; Vitiello, A. The advantages of drug treatment with statins in patients with SARS-CoV-2 infection. Wien. Klin. Wochenschr. 2021, 16, 1-8. [CrossRef]

58. Subir, R.; Jagat, J.M.; Kalyan, K.G. Pros and cons for use of statins in people with coronavirus disease-19 (COVID-19). Diabetes Metab. Syndr. 2020, 14, 1225-1229. [CrossRef] [PubMed]

59. Mitacchione, G.; Schiavone, M.; Curnis, A.; Arca, M.; Antinori, S.; Gasperetti, A.; Mascioli, G.; Severino, P.; Sabato, F.; Caracciolo, M.M.; et al. Impact of prior statin use on clinical outcomes in COVID-19 patients: Data from tertiary referral hospitals during COVID-19 pandemic in Italy. J. Clin. Lipidol. 2021, 15, 68-78. [CrossRef]

60. Daniels, L.B.; Sitapati, A.M.; Zhang, J.; Zou, J.; Bui, Q.M.; Ren, J.; Longhurst, C.A.; Criqui, M.H.; Messer, K. Relation of Statin Use Prior to Admission to Severity and Recovery Among COVID-19 Inpatients. Am. J. Cardiol. 2020, 136, 149-155. [CrossRef] [PubMed]

61. Kusama, T.; Mukai, M.; Ayaki, M.; Imamura, F.; Tatsuta, M.; Matsumoto, Y.; Nakamura, H.; Inoue, M. Inhibition of lysophosphatidic acid-induced RhoA activation and tumor cell invasion by 3-hydroxy-3-methylglutaryl-coenzyme A reductase inhibitors. Int. J. Oncol. 2003, 23, 1173-1178. [CrossRef]

62. Kaneyuki, U.; Ueda, S.; Yamagishi, S.; Kato, S.; Fujimura, T.; Shibata, R.; Hayashida, A.; Yoshimura, J.; Kojiro, M.; Oshima, K.; et al. Pitavastatin inhibits lysophosphatidic acid-induced proliferation and monocyte chemoattractant protein-1 expression in aortic smooth muscle cells by suppressing Rac-1-mediated reactive oxygen species generation. Vasc. Pharmacol. 2007, 46, 286-292. [CrossRef] [PubMed]

63. Marjot, T.; Webb, G.J.; Barritt, A.S.; Moon, A.M.; Stamataki, Z.; Wong, V.W.; Barnes, E. COVID-19 and liver disease: Mechanistic and clinical perspectives. Nat. Rev. Gastroenterol. Hepatol. 2021, 18, 348-364. [CrossRef] 
64. Trovato, F.M.; Zia, R.; Napoli, S.; Wolfer, K.; Huang, X.; Morgan, P.E.; Husbyn, H.; Elgosbi, M.; Lucangeli, M.; Miquel, R.; et al. Dysregulation of the LPC-ATX-LPA axis in ACLF is associated with mortality and systemic inflammation via LPA-dependent monocyte activation. Hepatology 2021, 3, 22. [CrossRef]

65. Guirao, J.J.; Cabrera, C.M.; Jiménez, N.; Rincón, L.; Urra, J.M. High serum IL-6 values increase the risk of mortality and the severity of pneumonia in patients diagnosed with COVID-19. Mol. Immunol. 2020, 128, 64-68. [CrossRef] [PubMed]

66. Herold, T.; Jurinovic, V.; Arnreich, C.; Lipworth, B.J.; Hellmuth, J.C.; von Bergwelt-Baildon, M.; Klein, M.; Weinberger, T. Elevated levels of IL-6 and CRP predict the need for mechanical ventilation in COVID-19. J. Allergy Clin. Immunol. 2020, 146, 128-136.e4. [CrossRef]

67. Meng, G.; Tang, X.; Yang, Z.; Zhao, Y.; Curtis, J.M.; McMullen, T.P.W.; Brindley, D.N. Dexamethasone decreases the autotaxinlysophosphatidate-inflammatory axis in adipose tissue: Implications for the metabolic syndrome and breast cancer. FASEB J. 2018, 13, 1226. [CrossRef] [PubMed]

68. Meng, G.; Wuest, M.; Tang, X.; Dufour, J.; McMullen, T.P.W.; Wuest, F.; Murray, D.; Brindley, D.N. Dexamethasone Attenuates X-Ray-Induced Activation of the Autotaxin-Lysophosphatidate-Inflammatory Cycle in Breast Tissue and Subsequent Breast Fibrosis. Cancers 2020, 12, 999. [CrossRef] [PubMed]

69. Tanaka, M.; Okudaira, S.; Kishi, Y.; Ohkawa, R.; Iseki, S.; Ota, M.; Noji, S.; Yatomi, Y.; Aoki, J.; Arai, H. Autotaxin stabilizes blood vessels and is required for embryonic vasculature by producing lysophosphatidic acid. J. Biol. Chem. 2006, 281, 25822-25830. [CrossRef]

70. van Meeteren, L.A.; Ruurs, P.; Stortelers, C.; Bouwman, P.; van Rooijen, M.A.; Pradere, J.P.; Pettit, T.R.; Wakelam, M.J.; SaulnierBlache, J.S.; Mummery, C.L.; et al. Autotaxin, a secreted lysophospholipase D, is essential for blood vessel formation during development. Mol. Cell. Biol. 2006, 26, 5015-5022. [CrossRef]

71. Fotopoulou, S.; Oikonomou, N.; Grigorieva, E.; Nikitopoulou, I.; Paparountas, T.; Thanassopoulou, A.; Zhao, Z.; Xu, Y.; Kontoyiannis, D.L.; Remboutsika, E.; et al. ATX expression and LPA signalling are vital for the development of the nervous system. Dev. Biol. 2010, 339, 451-464. [CrossRef]

72. Yukiura, H.; Hama, K.; Nakanaga, K.; Tanaka, M.; Asaoka, Y.; Okudaira, S.; Arima, N.; Inoue, A.; Hashimoto, T.; Arai, H.; et al. Autotaxin regulates vascular development via multiple lysophosphatidic acid (LPA) receptors in zebrafish. J. Biol. Chem. 2011, 286, 43972-43983. [CrossRef]

73. Gralinski, L.E.; Menachery, V.D.; Morgan, A.P.; Totura, A.L.; Beall, A.; Kocher, J.; Plante, J.; Harrison-Shostak, D.C.; Schafer, A.; Pardo-Manuel de Villena, F.; et al. Allelic Variation in the Toll-Like Receptor Adaptor Protein Ticam2 Contributes to SARS-Coronavirus Pathogenesis in Mice. G3 Bethesda 2017, 7, 1653-1663. [CrossRef] [PubMed]

74. Gralinski, L.E.; Ferris, M.T.; Aylor, D.L.; Whitmore, A.C.; Green, R.; Frieman, M.B.; Deming, D.; Menachery, V.D.; Miller, D.R.; Buus, R.J.; et al. Genome Wide Identification of SARS-CoV Susceptibility Loci Using the Collaborative Cross. PLoS Genet. 2015, 11, e1005504. [CrossRef] [PubMed]

75. Kanda, H.; Newton, R.; Klein, R.; Morita, Y.; Gunn, M.D.; Rosen, S.D. Autotaxin, an ectoenzyme that produces lysophosphatidic acid, promotes the entry of lymphocytes into secondary lymphoid organs. Nat. Immunol. 2008, 9, 415-423. [CrossRef]

76. Takeda, Y.; Matoba, K.; Kawanami, D.; Nagai, Y.; Akamine, T.; Ishizawa, S.; Kanazawa, Y.; Yokota, T.; Utsunomiya, K. ROCK2 Regulates Monocyte Migration and Cell to Cell Adhesion in Vascular Endothelial Cells. Int. J. Mol. Sci. 2019, 20, 1331. [CrossRef] [PubMed]

77. Rizza, C.; Leitinger, N.; Yue, J.; Fischer, D.J.; Wang, D.A.; Shih, P.T.; Lee, H.; Tigyi, G.; Berliner, J.A. Lysophosphatidic acid as a regulator of endothelial/leukocyte interaction. Lab. Investig. 1999, 79, 1227-1235. [PubMed]

78. Shlyonsky, V.; Naeije, R.; Mies, F. Possible role of lysophosphatidic acid in rat model of hypoxic pulmonary vascular remodeling. Pulm. Circ. 2014, 4, 471-481. [CrossRef] [PubMed]

79. Ray, R.; Rai, V. Lysophosphatidic acid converts monocytes into macrophages in both mice and humans. Blood 2017, 129, 1177-1183. [CrossRef]

80. Ninou, I.; Sevastou, I.; Magkrioti, C.; Kaffe, E.; Stamatakis, G.; Thivaios, S.; Panayotou, G.; Aoki, J.; Kollias, G.; Aidinis, V. Genetic deletion of Autotaxin from CD11b+ cells decreases the severity of experimental autoimmune encephalomyelitis. PLoS ONE 2020, 15, e0226050. [CrossRef]

81. Santos-Nogueira, E.; Lopez-Serrano, C.; Hernandez, J.; Lago, N.; Astudillo, A.M.; Balsinde, J.; Estivill-Torrus, G.; de Fonseca, F.R.; Chun, J.; Lopez-Vales, R. Activation of Lysophosphatidic Acid Receptor Type 1 Contributes to Pathophysiology of Spinal Cord Injury. J. Neurosci. 2015, 35, 10224-10235. [CrossRef]

82. Martino, A.; Volpe, E.; Baldini, P.M. The influence of lysophosphatidic acid on the immunophenotypic differentiation of human monocytes into dendritic cells. Haematologica 2006, 91, 1273-1274.

83. Chen, R.; Roman, J.; Guo, J.; West, E.; McDyer, J.; Williams, M.A.; Georas, S.N. Lysophosphatidic acid modulates the activation of human monocyte-derived dendritic cells. Stem Cells Dev. 2006, 15, 797-804. [CrossRef]

84. Siegal, F.P.; Kadowaki, N.; Shodell, M.; Fitzgerald-Bocarsly, P.A.; Shah, K.; Ho, S.; Antonenko, S.; Liu, Y.J. The nature of the principal type 1 interferon-producing cells in human blood. Science 1999, 284, 1835-1837. [CrossRef]

85. Saichi, M.; Ladjemi, M.Z.; Korniotis, S.; Rousseau, C.; Ait Hamou, Z.; Massenet-Regad, L.; Amblard, E.; Noel, F.; Marie, Y.; Bouteiller, D.; et al. Single-cell RNA sequencing of blood antigen-presenting cells in severe COVID-19 reveals multi-process defects in antiviral immunity. Nat. Cell Biol. 2021, 23, 538-551. [CrossRef] 
86. Zhou, R.; To, K.K.; Wong, Y.C.; Liu, L.; Zhou, B.; Li, X.; Huang, H.; Mo, Y.; Luk, T.Y.; Lau, T.T.; et al. Acute SARS-CoV-2 Infection Impairs Dendritic Cell and T Cell Responses. Immunity 2020, 53, 864-877.e5. [CrossRef]

87. Sánchez-Cerrillo, I.; Landete, P.; Aldave, B.; Sánchez-Alonso, S.; Sánchez-Azofra, A.; Marcos-Jiménez, A.; Ávalos, E.; AlcarazSerna, A.; de Los Santos, I.; Mateu-Albero, T.; et al. COVID-19 severity associates with pulmonary redistribution of CD1c+ DCs and inflammatory transitional and nonclassical monocytes. J. Clin. Investig. 2020, 130, 6290-6300. [CrossRef] [PubMed]

88. Hadjadj, J.; Yatim, N.; Barnabei, L.; Corneau, A.; Boussier, J.; Smith, N.; Péré, H.; Charbit, B.; Bondet, V.; Chenevier-Gobeaux, C.; et al. Impaired type I interferon activity and inflammatory responses in severe COVID-19 patients. Science 2020, 369, 718-724. [CrossRef] [PubMed]

89. Cisse, B.; Caton, M.L.; Lehner, M.; Maeda, T.; Scheu, S.; Locksley, R.; Holmberg, D.; Zweier, C.; den Hollander, N.S.; Kant, S.G.; et al. Transcription factor E2-2 is an essential and specific regulator of plasmacytoid dendritic cell development. Cell 2008, 135, 37-48. [CrossRef] [PubMed]

90. Guo, L.; He, P.; No, Y.R.; Yun, C.C. Krüppel-like factor 5 incorporates into the $\beta$-catenin/TCF complex in response to LPA in colon cancer cells. Cell. Signal. 2015, 27, 961-968. [CrossRef] [PubMed]

91. Spagnolo, P.; Balestro, E.; Aliberti, S.; Cocconcelli, E.; Biondini, D.; Casa, G.D.; Sverzellati, N.; Maher, T.M. Pulmonary fibrosis secondary to COVID-19: A call to arms? Lancet Respir. Med. 2020, 8, 750-752. [CrossRef]

92. George, P.M.; Wells, A.U.; Jenkins, R.G. Pulmonary fibrosis and COVID-19: The potential role for antifibrotic therapy. Lancet Respir. Med. 2020, 6, 3022. [CrossRef]

93. Vasarmidi, E.; Tsitoura, E.; Spandidos, D.A.; Tzanakis, N.; Antoniou, K.M. Pulmonary fibrosis in the aftermath of the COVID-19 era (Review). Exp. Ther. Med. 2020, 20, 2557-2560. [CrossRef]

94. Stuart, T.; Butler, A.; Hoffman, P.; Hafemeister, C.; Papalexi, E.; Mauck, W.M., III; Hao, Y.; Stoeckius, M.; Smibert, P.; Satija, R. Comprehensive Integration of Single-Cell Data. Cell 2019, 177, 1888-1902.e21. [CrossRef]

95. Travaglini, K.J.; Nabhan, A.N.; Penland, L.; Sinha, R.; Gillich, A.; Sit, R.V.; Chang, S.; Conley, S.D.; Mori, Y.; Seita, J.; et al. A molecular cell atlas of the human lung from single-cell RNA sequencing. Nature 2020, 587, 619-625. [CrossRef]

96. Fanidis, D.; Moulos, P. Integrative, normalization-insusceptible statistical analysis of RNA-Seq data, with improved differential expression and unbiased downstream functional analysis. Brief. Bioinform. 2020, 22, 156. [CrossRef]

97. Anders, S.; Huber, W. Differential expression analysis for sequence count data. Genome Biol. 2010, 11, R106. [CrossRef] [PubMed]

98. Love, M.I.; Huber, W.; Anders, S. Moderated estimation of fold change and dispersion for RNA-seq data with DESeq2. Genome Biol. 2014, 15, 550. [CrossRef]

99. Ritchie, M.E.; Phipson, B.; Wu, D.; Hu, Y.; Law, C.W.; Shi, W.; Smyth, G.K. limma powers differential expression analyses for RNA-sequencing and microarray studies. Nucleic Acids Res. 2015, 43, e47. [CrossRef]

100. McCarthy, D.J.; Chen, Y.; Smyth, G.K. Differential expression analysis of multifactor RNA-Seq experiments with respect to biological variation. Nucleic Acids Res. 2012, 40, 4288-4297. [CrossRef] [PubMed]

101. Yang, W.; Rosenstiel, P.C.; Schulenburg, H. ABSSeq: A new RNA-Seq analysis method based on modelling absolute expression differences. BMC Genom. 2016, 17, 484. [CrossRef] [PubMed] 